\title{
Under the Shade of the Achuil Tree
}

\section{Warwick Sprawson}

Often I Remember the whistling, soft at first like a forest bird, then getting louder with a sound like breaking branches. When the mortars found their range the earth shook and the thatched huts burnt like flares. Women were screaming, parents were calling for their children, bullets stung through the air like angry wasps. People were running everywhere. I went to my parents' hut but they weren't there. I ran to the edge of the village and hid in the tall grasses like my father had told me. Their sharp leaves cut my bare knees as groups of djellabas ran passed. The shooting lasted two hours. We had no guns. We were farmers with our cows, millet and maize.

At dawn our huts were smoking black rings on the red dirt. The cattle, goats and chickens were gone. Only the bodies of the people remained, sprawled where they fell. Some black rings enclosed piles of ashes and bone; people trapped in their hut and burnt alive. The bodies of men floated in the river, arms tied, hacked with machetes to save bullets.

I found my parents near the luaak, the cattle enclosure, either side of my youngest brother, the three of them in a row, limbs twisted, fingers clutching the earth.

I tried to dig a grave with a stick but it was February and the ground was too hard. I found some half burnt thatch and covered them the best I could. I was eight years old.

A few other villagers survived the attack. Deng, a friend who lived two huts from ours, and Benson, a man who was respected for owning many cows and who had seven traditional scars on his forehead. Benson told us we had to leave. We had to walk east towards the border.

I didn't want to leave. I wanted to wait for my brothers and sisters to return. I was sure they had been hiding like me. 
Benson told me he had seen my oldest brother, Benjamin, hiding in the forest the night before. Benjamin told him to tell everyone to meet him at the border.

We ran towards the dawn, ducking into the tall grass whenever we heard a noise ahead.

When I first saw Australia from the plane it was just before dawn and I marvelled at all the cooking fires. It wasn't until we were driving past closed factories and shops that I realised they were electric lights and that Australia was a country that could afford to light up places where no people lived. I remember thinking how strange it was that some people could have too much and others too little.

The former immigration minister said that Sudanese have trouble integrating. He said we don't fit into the Australian way of life quickly. That was why he halved the number of Sudanese refugees allowed into this beautiful country. Maybe the immigration minister is correct in saying we have problems integrating. I am six foot seven and very, very black.

Some of the djellebas were black, others lighter skinned. Many times we hid in tall grass as they ran passed. Occasionally there was the sound of gunfire, which grew more distant as we ran away from our smouldering village. My feet were bloody from sharp leaves and roots. After several hours Deng fell and started crying for his parents but Benson told him to get up and have the courage of a Dinka.

Deng got up and kept running. He had nothing, not even a pair of shorts like me.

There was many times on that trek through Sudan when I thought we would die. I thought God had turned away from us, and kept looking away, as if waiting for every last boy to die. There were many boys heading to the border from villages like mine. Sometimes big aircraft flew overhead and dropped bombs on us. It was dry season and there was little food or water. Sometimes all we had to eat was mud. It filled your stomach and gave a little water but many died anyway. 
We referred to it as 'falling over'. A person would die mid-step. We left them where they fell, we had no choice - we were dead too, but still walking. Most died from dehydration. They went grey like ash, then almost white.

Nobody had enough tears to cry. There were piles of bones under the shade of trees where people had laid down and never got up. That became another term for death. To 'sit in the shade'. Some boys who made their way to the border said they had followed the piles of bones.

After two months Deng died. It was probably from lack of water, although he had also been bitten by a snake.

There were so many people fleeing the fighting that villages sometimes shamed themselves by refusing to share what food and water they had.

They didn't believe that the war would come for them too.

On my first day in Australia I was taken to a supermarket. The aisles were as wide as roads and lined with thousands of things in colourful packaging. I was asked what I would like to eat but there was nothing there I recognised as food. When I saw some eggs I was very relieved. I asked for some milk too and they bought me several litres. The supermarket had beef in white trays covered with clear plastic but I didn't like the look of that beef and said I didn't want any.

In truth there is a great variety of food in Australia but much of it smells and tastes strange. Even your milk is not the same as our rich, creamy Sudanese milk. As a boy, tending the cows, I used to squirt it straight in my mouth.

When we arrived at the Kakuma camp in Kenya we were just hips and heads. I looked for my brothers and sisters but they were not there.

Later, when I finally saw a map of Sudan, I saw we had walked 800 kilometres pursued by bullets, bombs, hunger, thirst, wild animals and disease. Maybe God was watching us after all because nobody should have survived that walk.

Kakuma was just a bare paddock and a few thorny achuil trees. 
There was no running water, no toilets or shelter from the sun. We made shelters from branches, plastic bags and grass, but the red dust still got into everything, into our eyes, mouths and the little food we found. The dust was so thick that later, when a car finally came to the camp, it had to drive with its headlights on even during the day. But it didn't matter; we were safe. When the UN dug a well it was the best water I had ever tasted.

I was in the camp for ten years. At the start it was very hard and we were hungry all the time, but slowly things improved as we organised the camp into zones and formed committees to improve facilities. It was in Kakuma that I attended my first ever class under the shade of an achuil tree. I traced English letters in the red dust with my finger. The first letter was ' $\mathrm{A}$ '. ' $\mathrm{A}$ ' for Australia. ' $\mathrm{A}$ 'for alive.

When I arrived in Australia I found a job loading boxes onto pallets. The boxes were very heavy but I didn't mind. When that job finished at five P.M I changed my clothes, ate my dinner then started to work as a security guard. Security was a good job as when it was quiet I could study English. It was a very hard schedule and I usually only had four or five hours sleep a night, but I didn't mind.

All the money I saved I sent back to the camp, to Benson, to the friends I'd made there. I remembered the lessons of the elders, of Benson. Don't forget.

Now I am an Australian citizen and love this country - its peace and freedom - very much. But maybe some people still think I am having trouble integrating. I am still six foot seven and very, very black.

I haven't forgotten. Sometimes at night I still dream about herding the gentle cows of Dinkaland. 